\title{
A VILLAMOSENERGIA-FELHASZNÁLÁS VÁLTOZÁSA
}

\author{
Lipták Róbert \\ Ph.D. hallgató, Miskolci Egyetem, Fizikai és Elektrotechnikai Intézet, \\ Elektrotechnikai és Elektronikai Intézeti Tanszék \\ 3515 Miskolc, Miskolc-Egyetemváros, e-mail: elkrobi@uni-miskolc.hu \\ Hadházi Tibor \\ villamosmérnök alapszakos hallgató, Miskolci Egyetem, Fizikai és Elektrotechnikai Intézet, \\ Elektrotechnikai és Elektronikai Intézeti Tanszék \\ 3515 Miskolc, Miskolc-Egyetemváros, e-mail: hadhazitobor97@gmail.com
}

\begin{abstract}
Absztrakt
A tanulmány a jelenlegi villamosenergia felhasználást, valamint a közeljövőben prognosztizálható villamos energia fogyasztást mutatja be, továbbá ezen fejlesztések és lehetséges beruházásokat irja le. A folyamatosan növekvö villamosenergia igény egy részét képesek vagyunk az újonnan létesülö megújuló energiaforrásokkal üzemelö erömüvekkel ellátni, azonban továbbra is jelentös az import energia függöségünk. Nem csak a villamosenergia iránti igény növekszik évröl évre, hanem a napi csúcsterhelések is évröl évre egyre nagyobbak. Éves szinten a hazai villamosenergia-igény több mint harmadát importból fedezzük. Ennek több oka is ismeretes. Egyrészt a hazai erömüpark elöregedett, igy hatékonyságuk jelentősen eltér az elvártaktól, igy üzemeltetésük sok esetben nagyobb költséggel jár, mint amennyiért a megtermelt villamos energiát el tudják adni; másrészt a külföldi termelök a kiemelkedö hatékonyságú erömüveik miatt, Az üvegházhatás és globális felmelegedés megakadályozáshoz a megújuló energiaforrások kapacitásának további bövitése szükséges. Valamint alap- és menetrendtartó erömüvek épitésére is szükség van. További kérdés még, hogy a jövőre tekintve, hogyan változhat meg a villamosenergia-termelés, hogyan lehet környezetbarátabb, illetve az egyre nagyobb fogyasztói igényeket miként lehet kielégiteni.
\end{abstract}

Kulcsszavak: villamosenergia felhasználás, erömüvek, megújuló energia, villamosenergia igény, villamos hálózat

\begin{abstract}
This paper presents the current electricity consumption as well as the electricity consumption that can be predicted in the near future. It also describes these developments and potential investments. We are able to supply part of the constantly growing demand for electricity with newly established renewable energy power plants, but our dependence on imported energy is still significant. Not only is the demand for electricity increasing year by year, but the daily peak loads are also increasing year by year. On an annual basis, we cover more than a third of the domestic electricity demand from imports. On the one hand, the domestic power plant park is obsolete, so their efficiency differs significantly from expectations, so in many cases their operation is more expensive than they can sell the electricity produced; on the other hand, foreign producers due to their highly efficient power plants. Further capacity building for renewable energy sources is needed to prevent the greenhouse effect and global warming. There is also a need to build basic and scheduled power plants. Another question is how, in the
\end{abstract}


future, electricity production can change, how it can be more environmentally friendly and how growing consumer needs can be met.

Keywords: electricity consumption, power plants, renewable energy, electricity demand, electricity network

\section{Bevezetés}

Napjainkban a villamosenergia szerves részévé vált életünknek, ezt leginkább akkor érzékeljük, amikor egy estleges áramkimaradás során pár órára nélkülöznünk kell a villamosenergiát. Ezen idő alatt úgy érezhetjük, hogy cselekvőképtelenné váltunk. A háztartási eszközeink és tömegközlekedési eszközeink túlnyomó többségének a müködéséhez is villamosenergia szükséges, ilyenek például a mosógép, hütő, fagyasztó, porszívó, robotgép, villanysütő, mikrohullámú sütő, vonat, metró, villamos, trolibusz, elektromos buszok és elektromos autók. A világításhoz is általánosságban az elektromos áramot használjuk. A telefonok, laptopok, TV-k és egyéb infokommunikációs eszközök müködéséhez szintén nélkülözhetetlen a villamosenergia. Egyes eszközök akkumulátorok segítségévél tárolják ezt az energiát, valamint meg kell említenünk, hogy az internet és wifi müködéséhez is szükség van villamosenergiára. Az elmúlt időkben elterjedtebbé vált a klímák használata, ezen eszközök használatával és a technikai fejlődés során egyre több villamosenergiára van szükségünk.

Az előbbiekben felsorolt eszközök nélkül szinte már el sem tudjuk képzelni az életünket, föleg a koronavírus idején, amikor a legtöbb tanuló/hallgató távoktatásban tanul, illetve legtöbben home office-ban dolgoznak. Mivel az előbb említett eszközök teljesen az életünk részévé váltak, így gyakran a villamosenergiára szinte természeti jelenségként tekintünk. Pedig a villamosenergia-termelése és szállítása mögött komoly feladatok és munkák vannak. A termelés során, pedig hatással vagyunk a környezetünkre. A következőkben szeretnénk bemutatni, hogy az elmúlt években, miben változott a villamosenergia-termelés és ez, milyen hatással van a környezetre, valamint szeretném bemutatni, hogy a jövőre tekintve, hogyan változhat meg a villamosenergia-termelés, hogyan lehet környezetbarátabb, illetve az egyre nagyobb fogyasztói igényeket minkét lehet kielégíteni.

\section{Magyarország villamosenergia-termelése 2010 és 2019 között}

Az 1. ábrán a KSH adatait felhasználva láthatjuk, hogy Magyarországon 2010 és 2019 között évekre lebontva, mennyi villamosenergiát használtunk fel, illetve ez a villamosenergia, hogyan oszlik meg a Magyarországon megtermelt, illetve import villamosenergia arányában.

Ahogyan láthatjuk az elmúlt 11 év közül 2013-ban használtunk a legkevesebb villamosenergiát és 2019-ben a legtöbbet, ehhez hasonló mennyiséget 2007-ben használtunk. A KSH adati alapján 1990 és 2000 között átlagban $39.390 \mathrm{GWh}$ energiát használtunk fel. 2000 és 2010 között átlagosan 48.816 GWh-t használtunk. 2010 és 2019 között pedig 50.246 GWh-t. Ezekből látható, hogy egyre több és több villamosenergiát használunk fel, amely folyamat vélhetően a következő években is hasonló tendenciát fog mutatni.

A 2. ábra megmutatja, hogyan oszlik meg a Magyarországon termelt villamosenergia fosszilis és megújuló energiaforrások arányában GWh-ban megadva. Mivel nem minden évben használunk ugyanannyi villamosenergiát, így nem látszik, hogy az összesen elhasznált energia hány százaléka származik a fosszilis és megújuló energiaforrásokból, ezt a 3. ábra jobban fogja szemléltetni. 


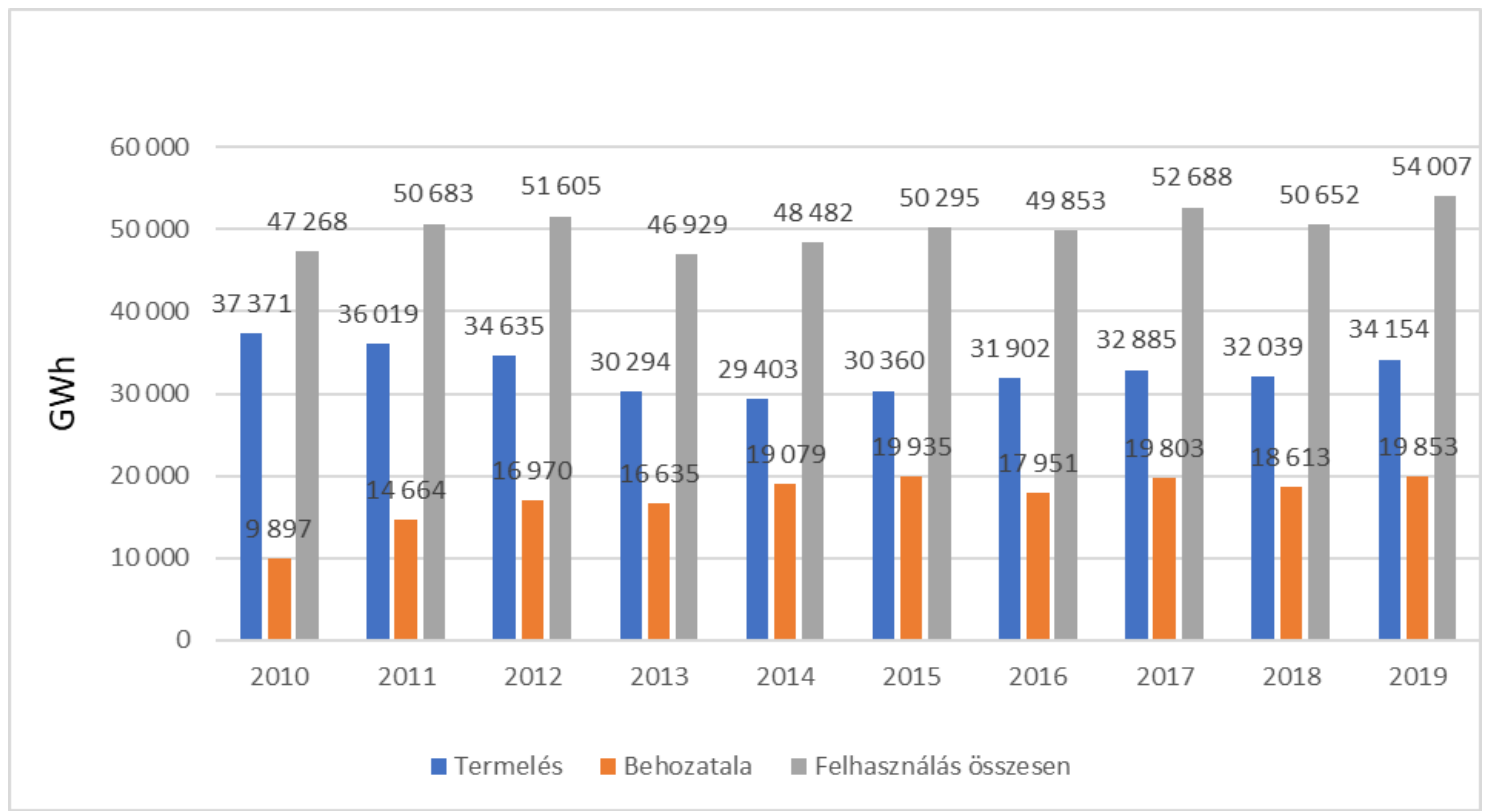

1. ábra. Magyarország villamosenergia-felhasználásának változása 2010 és 2019 között.

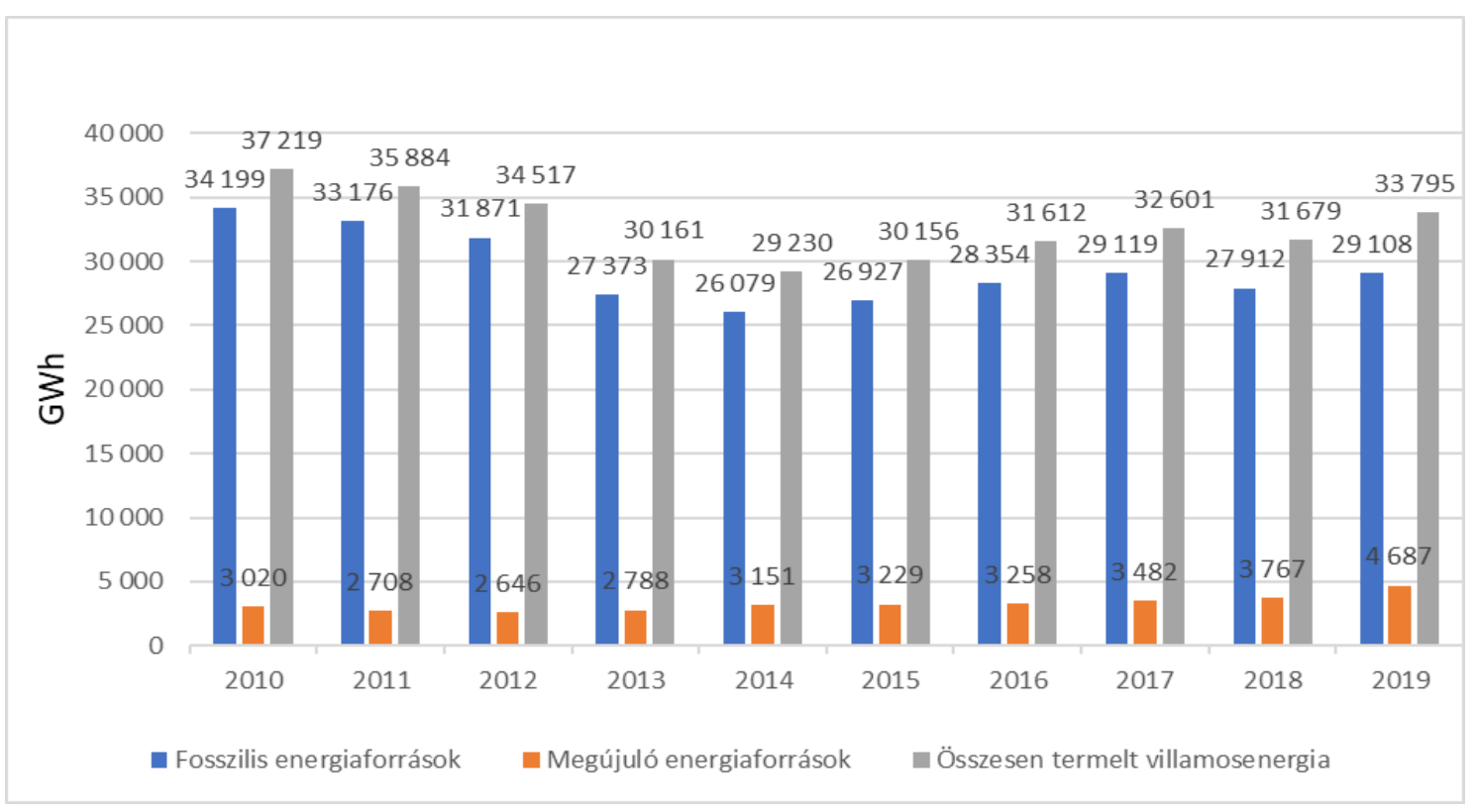

2. ábra. Magyarországon termelt villamosenergia és megoszlása. 


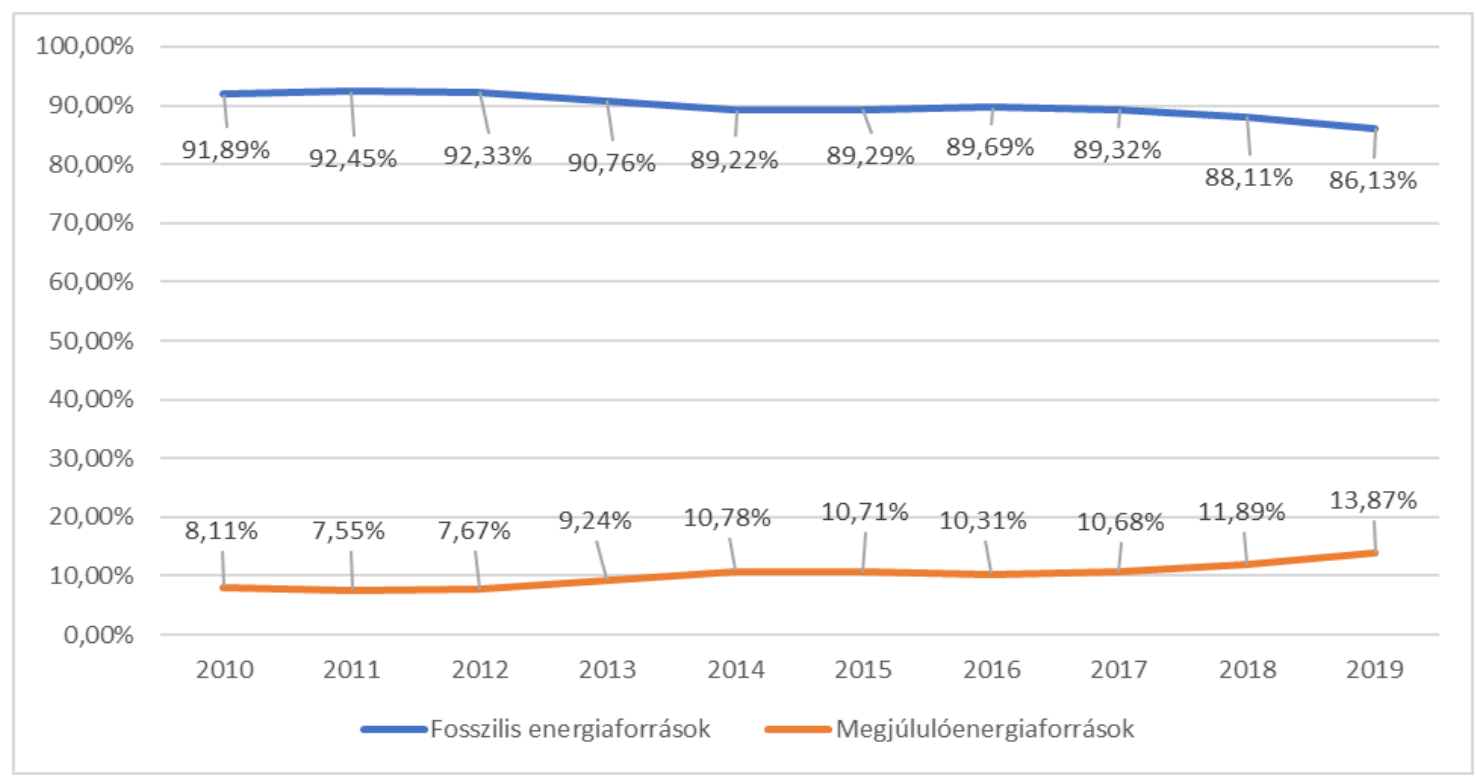

3. ábra. Magyarországon termelt villamosenergia és megoszlása százalékban.

A 3. ábrából már jobban kivehető, hogy a Magyarországon termelt összes villamosenergia hány százaléka, milyen energiaforrásból származik. Ahogy láthatjuk, a fosszilis energiaforrások folyamatosan csökkenek, míg a megújuló energiaforrásokból származó villamosenergia aránya folyamatosan nő. Ahogyan láthattuk a folyamatosan növekvő villamosenergia igény egy részét képesek vagyunk az újonnan létesülő megújulóenergiaforrásokkal üzemelő erőmüvekkel, azonban továbbra is jelentős az import energia függőségünk.

Az üvegházhatás és globális felmelegedés megakadályozáshoz a megújuló energiaforrások kapacitásának további bővítése szükséges. Azt, hogy a következő években, hogyan fognak alakulni a villamosenergia fogyasztási szokások, illetve a termelt energia, hogyan oszlik meg megújuló és nem megújuló energiaforrások arányában, nehéz megjósolni. Azonban a rendelkezésre álló több évtizedes adathalmaz nagy segítségünkre lehet. Az elmúlt évtizedek fogyasztási adataiból jól látszik, hogy évente átlagosan 1,4\%-kal növekszik a villamosenergia-felhasználás. 2030-ra a hazai villamosenergiafelhasználás 15\%-kal nagyobb lehet a jelenlegihez képest. Ezzel meghaladhatja a 62.025 GWh-t.

\section{Magyarország erőmühátterének jövőbeli átalakulása}

A Nemzeti Energiastratégia célkitüzései között a napelemes erőművek és a biomassza alapú erőművek létesítésének növelése várható az új atomerőmüvi blokkok mellett. A prognózist a fenti adatokra, valamint arra építhetjük, hogy 2030-ra üzembe kerülhet Paks II, továbbá új napelemes és biomassza erőmüvek létesülnek. Arra kicsi az esély, hogy Magyarországon a hagyományos és megújuló energiaforrások aránya a villamosenergia-termelésben keresztezni fogja egymást, azaz, hogy a megújuló energiaforrások aránya fog dominálni. Ez azért történhet, mert Paks II. megépülésével a hagyományos energiaforrásokból származó energia maradhat a meghatározó, azok közül is az atomenergia. Az új erőmü megépülésével energia függőségünk jelentősen csökkenhet, valamint tekintettel arra, hogy az atomerőmü a müködése közben a többi erőművekhez képest a legkevesebb üvegház hatású gázt bocsájtja ki, így a klímaváltozás megakadályozásához is jelentősen hozzájárul. Azonban nem szabad 
figyelmen kívül hagyni, hogy a hazai -hagyományos- erőműveink szinte kizárólag külföldről származó üzemanyaggal fog müködni, ezért a külföldi üzemanyagfüggőségünk tovább fog növekedni (Stróbl, 2015; Szücs, 2019). Amennyiben az atomenergia és a megújuló energiaforrások fognak dominálni a villamos energiatermelésben és a szén, lignit, valamint az egyéb fosszilis anyagokat égető erőmüvek háttérbe szorulnak, úgy a karbonlábnyomunk is méréskelhető.

Azt sem szabad figyelmen kívül hagyni, hogy nem csak a villamosenergia iránti igény növekszik évről évre, hanem a napi csúcsterhelések is évről évre egyre nagyobbak. A napi csúcsterhelések az utóbbi években jellemzően 6.500 és 7.000 MW között alakultak, amely értékek meghaladják a hazai erőmüpark nettó kapacitását, így az importfüggőség igen jelentős (Stróbl, 2015). Éves szinten a hazai villamosenergia-igény több, mint harmadát importból fedezzük. Ennek több oka is ismeretes. Egyrész a hazai erőmüpark elöregedett, így hatékonyságuk jelentősen eltér az elvártaktól, így üzemeltetésük sok esetben nagyobb költséggel jár, mint amennyiért a megtermelt villamos energiát el tudják adni; másrészt a külföldi termelők a kiemelkedő hatékonyságú erőműveik miatt, vagy a saját országbeli fogyasztási igény hiánya miatt olcsóbban tudják a rendelkezésünkre bocsátani a villamosenergiát (Morvai, 2012). A közeljövőben ezek az arányok jelentősen nem fognak változni, annak ellenére sem, hogy nagyvolumenű erőmüépítések várhatók (Paks II és napelemes erőművek). Ennek legfőbb oka, hogy számos hazai nagyerőmü még ebben az évtizedben eléri a tervezett, illetve a már korábban meghosszabbított élettartamát, így azok leállítása elkerülhetetlen. A Mátrai Erőmü várhatóan 2025-2026 körül olyan döntés előtt fog állni, amely az erőmü teljeskörü felújítását, vagy a teljes leállítását fogja eredményezni. Ha az utóbbi valósul meg, akkor mintegy 1.000 MW kapacitás fog kiesni a magyar villamosenergia-rendszerből, amit csak részben fog tudni kompenzálni az addig létesítendő új 1.500$2.000 \mathrm{MW}$ teljesítményü napelemes erőmüpark. Megoldást jelenthetnek az új típusú biomassza alapú erőművek, amelyek a hagyományos égetéses technológia mellett a gázosítás, vagy éppen a pirolízis módszerét alkalmazzák (Szücs, 2019; Bodnár, 2017).

Szintén nem elfelejtendő, hogy míg a hagyományos energiaforrásokat, vagy a biomasszát, illetve biogázt hasznosító erőművek éves teljesítménykihasználtsága átlagosan 70-90\% között alakul, addig a napelemes erőmüvek 10-15\%-át használják ki a kapacitásuknak (Bükki, 2004). Ráadásul a napelemek termelése időhöz kötött és időjárásfüggö, így nem alkalmas teljes mértékben kiváltani a hagyományos erőműveket. Mindezeket figyelembe véve elkerülhetetlen a helyi-, vagy az ipari méretü villamosenergia-tárolás bevezetése. Helyi szinten az akkumulátoros és a forgó mozgáson alapuló tárolók, ipari méretekben a hidrogén alapú, vagy a szivattyús-tározós vízerőművek jelenthetnek megoldást (Bodnár, 2017).

A fokozatosan kieső teljesítmények pótlására pedig további korszerü erőművek, elsősorban biomassza gázosításán vagy pirolízisén alapúló, építése szükséges, hogy elkerülhető legyen az importtól való függőség további növekedése és a környezetbarátabb villamosenergia-termelés megvalósítható legyen; a villamosenergia fajlagos karbonlábnyomának a csökkentése megtörténjen.

A növekvő tendencia miatt a bruttó hazai csúcsterhelés 2030-ra elérheti a 8.500-9.000 MW-ot. A jövőbeni erőmümixnek ezeket az igényeket kell kielégítenie.

Ha a megújulók fajlagos beruházási költségét nézzük, akkor az látható, hogy a biomassza erőmüvek költségei nem változnak, viszont a napelemes rendszerü- és a szélerőművek beruházási költsége jelentősen csökken. A napelemes erőmüvek beruházási költsége az elmúlt 10 évben kevesebb, mint a felére csökkent (Bodnár, 2019). A hagyományos erőmüvek közül jelenleg is és a jövőben is a nyílt ciklusú gázturbinás erőművek beruházási költsége a legalacsonyabb. A lignit- és széntüzelésű erőmüvek nagyon drágák lesznek a jövőben is és a villamosenergia-termelés karbonlábnyomának csökkenté- 
sének sem kedveznek. A gáztüzelésủekkel viszont az a probléma, hogy az üzemeltetési költségük nagyban függ a gáz árától, ez Magyarországon manapság is komoly gondot jelent (Ösz, 2011).

Jelenleg Magyarország a biomassza potenciáljának mintegy 15\%-át hasznosítja. Amennyiben a teljes potenciált biomassza tüzelésủ erőmüben hasznosítanánk, akkor mintegy $2.800 \mathrm{MW}$ összteljesítményü új erőművet létesíthetnénk. Ez csaknem 3 db Mátrai Erőmủ üzemeltetését tenné lehetővé (Bodnár, 2017). A Mátrai Erőmü hatásfoka jelenleg $29 \%$, de az újonnan üzembe helyezett ligniterőmüvek hatásfoka már a 43\%-os hatásfokot is elérhetné (Bodnár, 2017; Bodnár and Plásztán, 2016; Bihari, 2012; Tóth et al., 2011). Természetesen a települési szilárd hulladékok és az abból készülő másodtüzelőanyagok felhasználásának további bővítésében is gondolkodnunk kell. A célkitüzések azonban a napelemes rendszerek terjedésének kedveznek, így nem várható nagy mértékben a biomassza vagy a települési szilárd hulladék hasznosítására épülő erőmü. Amennyiben tovább folytatódik ez a célkitüzés, miszerint 2030-ig évente átlagosan 500 MW kapacitású új napelemes erőmüvet kell építeni, akkor 2030-ra a napelemes erőművek összkapacitása el fogja érni a 6.000 MW-ot. A napelemes erőmüvek beépített összkapacitása már az idei évben el fogja érni a Paksi Atomerőmü jelenlegi teljesítményét, azaz a 2.000 MW-ot (Stróbl, 2015).

\section{Erőmüvi kapacitások napjainkban és a jövőben}

Magyarország jelenlegi erőmű-összetételét a 4. ábra szemlélteti: $2.000 \mathrm{MW}$ atom, $700 \mathrm{MW}$ szén (első sorban lignit), 2.900 MW földgáz, $600 \mathrm{MW}$ olaj, $700 \mathrm{MW}$ megújuló energiaforrás a napelemes erömüvek nélkül, valamint kb. 1.300 MW napelemes erőmü, így összesen kb. $8.200 \mathrm{MW}$ beépített teljesítménnyel rendelkezünk jelenleg.

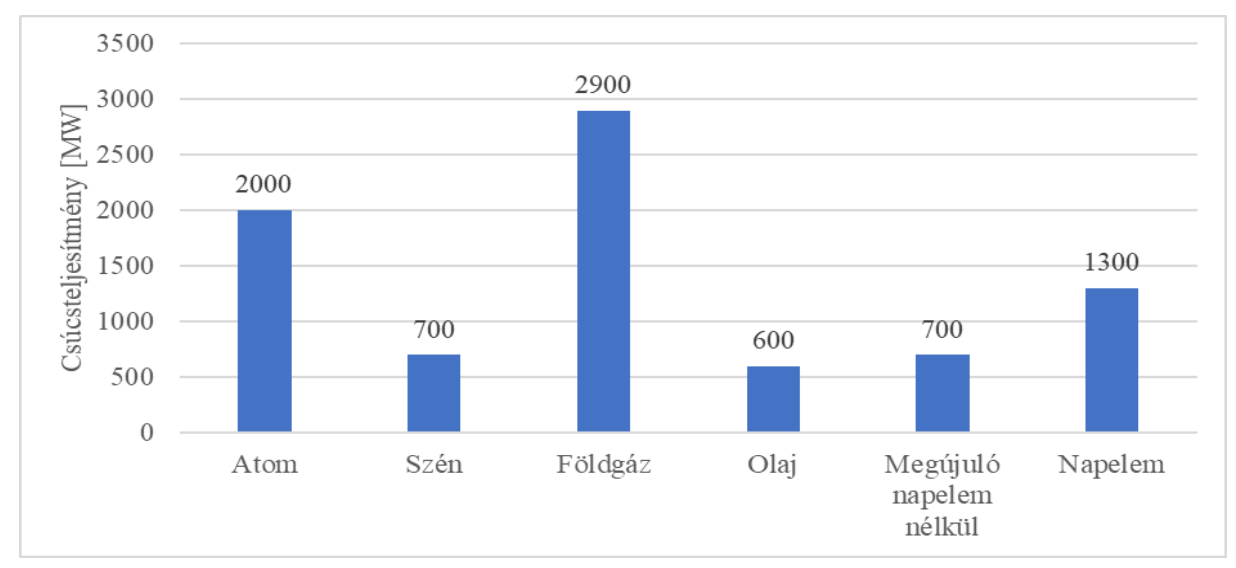

4. ábra. Beépittett erömüvi teljesitmények Magyarországon, 2021 tavaszán.

Az 5. ábrán megfigyelhető, hogy 2021-ben az atomenergia és a megújuló energiaforrások aránya egyformán 24,39\%-ot tesz ki az összes beépített erőmüvi teljesítmény tekintetében. A földgáz üzemü erőművek a 35,37\%-os részesedési aránnyal vezető szerepet fognak betölteni. A széntüzelés $8,54 \%$-ot, az olajtüzelés 7,32\%-ot fog képviselni. Továbbra sem szabad figyelmen kívül hagyni, hogy ezek csak a beépített kapacitásokra vonatkoznak. A villamosenergia-termelés körképe ettöl drasztikusan különbözik az erőművek éves csúcsteljesítmény-kihasználhatósága miatt. 


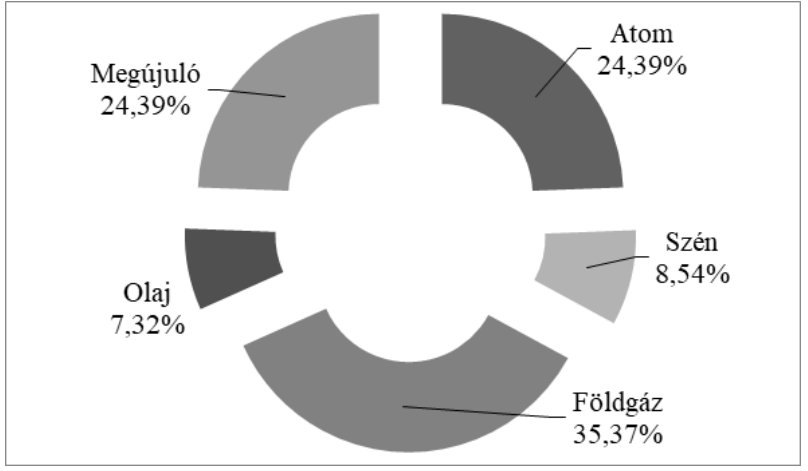

5. ábra. Beépittett erömüvi teljesitmények aránya Magyarországon, 2021 tavaszán.

A 6. ábra szemlélteti Magyarország 2030-ra várható erőmüvi teljesítmény-összetételét. Ha csak Paks 2 épülne meg és csak a Mátrai Erőmü kerülne leállításra, akkor közép/hosszú távon egy erőmüves országgá válnánk és egyik erőművünk sem magyar tüzelőanyaggal müködne. 2030-ra várhatóan a hagyományos erőművek részesedése a hazai villamosenergia-termelésben 83,77\%-ra fog csökkeni, míg a megújuló energiaforrások aránya 16,23\%-ra fog nőni köszönhetően a napelemes erőmúveknek.

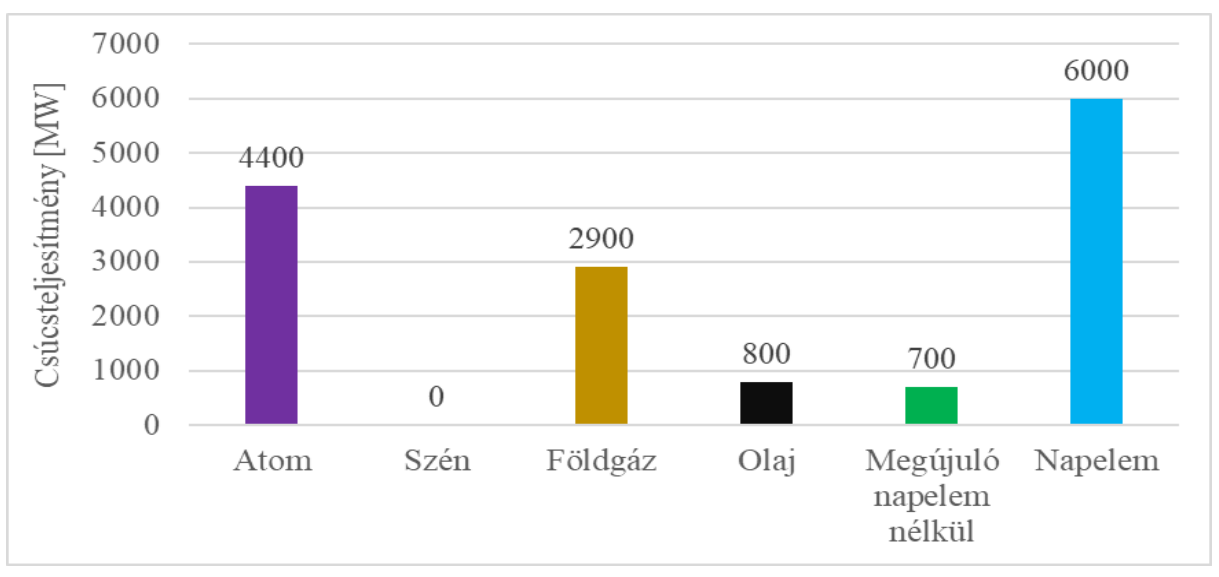

6. ábra. Beépitett erőmüvi teljesitmények Magyarországon, prognózis 2030.

\section{5. Összefoglalás}

Összességében elmondható, hogy a jövőben szükség lesz új erőművek építésére, a jelenleg még üzemelö, de folyamatosan elöregedő és leállítandó alap- és menetrendtartó erőmüvek, valamint a gyors kiegyensúlyozó képességgel rendelkező csúcserőművek pótlására. Az atomenergia mellett a lignit- és a biomassza tüzelésủ erőmüvek, valamint a folyamatosan csökkenő bekerülési költségü napelemes erőművek létesítésével növelhetjük Magyarország villamosenergia-rendszerének biztonságát. Azonban nem szabad elfelejteni, hogy a lignit- és a biomassza erőműveknél a legújabb generációkat, azaz a gázosításon és a pirolízisen alapuló rendszereket érdemes alkalmazni, illetve kooperálni a napelemes erőművekkel, ezáltal a Villamosenergia-Rendszer hatékonyabban üzemeltethető. 


\section{Köszönetnyilvánítás}

A cikkben ismertetett kutató munka az NTP-SZKOLL-20-0022 azonosítószámú „Fókusz'21 - Középpontban a közösség digitális kompetenciák fejlesztése által" projekt keretében valósult meg az Emberi Erőforrások Minisztériuma és az Emberi Erőforrás Támogatáskezelő támogatásával.

\section{Irodalom}

[1] Bodnár, I. (2019). Napelemek müködésének alapjai, a napelemes villamosenergia termelés elmélete és gyakorlati megvalósitása. Miskolci Egyetem, Micropress Kft. ISBN 978-615-00456-65.

[2] Stróbl, A. (2015). A magyarországi erőmüépités jövője, föbb kérdései. Előadásanyag, Energetikai Szakkollégium.

[3] Szücs, G. (megtekintés dátuma: 2021. március 2.) Magyarország villamos energia termelése és felhasználása 2018-ban. https://villanyautosok.hu/2019/11/12/magyarorszag-villamos-energiatermelese-es-felhasznalasa-2018-ban/

[4] Bodnár, I. (2017). Fás szárú biomasszák és települési szilárd hulladékok termikus hasznositása. Miskolci Egyetem, Micropress Kft. ISBN 978-963-12-7604-6.

https://doi.org/10.33895/mtk-2017.06.05

[5] Bodnár, I., Plásztán, B. (2016). Fás szárú biomasszák pirolitikus hasznosításának termokinetikai modellezése. GÉP, LXVII(3), pp. 5-12.

[6] Morvai, Gy. (2012). Villamosenergetika. Edutus Föiskola, p. 94.

[7] Bükki, G. (2004). Erömüvek. Müegyetemi Kiadó, p. 608.

[8] Ösz, J. (2011). Kapcsolt hö- és villamosenergia-termelés. BME.

[9] Bihari, P. (2012). Energetikai alapismeretek. BME, p. 232.

[10] Tóth, P., Bulla, M., Nagy, G. (2011). Energetika. p. 204. 